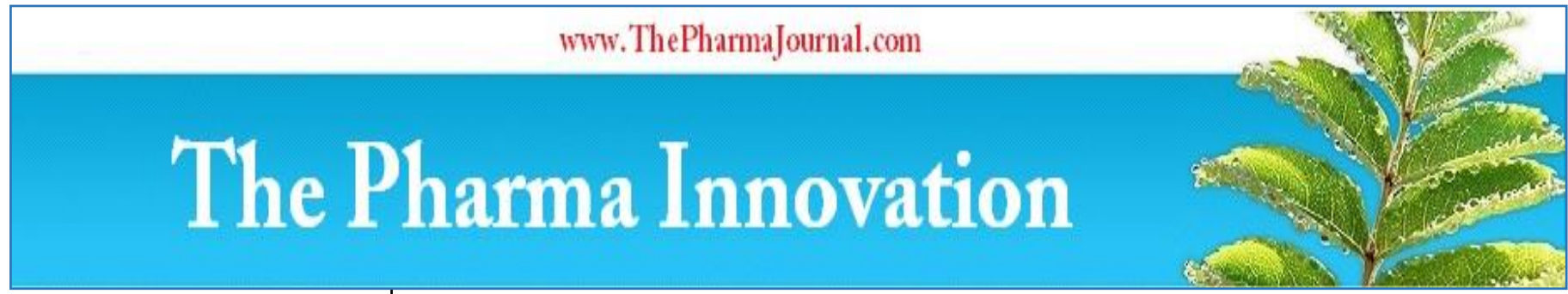

ISSN (E): 2277- 7695

ISSN (P): 2349-8242

NAAS Rating: $\mathbf{5 . 0 3}$

TPI 2020; SP-9(7): 164-165

(C) 2020 TPI

www.thepharmajournal.com

Received: 25-05-2020

Accepted: 26-06-2020

Rajasokkappan S

Veterinary Assistant Surgeon,

Malayandigoundanur,

Udumalaipettai, Tamil Nadu, India

\section{Rajan T}

Veterinary Assistant Surgeon,

Sellappampalayam,

Udumalaipettai, Tamil Nadu,

India

\section{Raghavendran VB}

Assistant Professor, Department. of Agronomy, Agriculture college and Research Institute, Madurai,

Tamil Nadu, India
Corresponding Author: Rajasokkappan S

Veterinary Assistant Surgeon,

Malayandigoundanur,

Udumalaipettai, Tamil Nadu,

India

\title{
Sorghum poisoning in a cow and it's successful management
}

\section{Rajasokkappan S, Rajan T and Raghavendran VB}

DOI: https://doi.org/10.22271/tpi.2020.v9.i7Sc.4956

\section{Abstract}

A cow was presented with a history of sudden fall in the barren land with frothy salivation near Veterinary Dispensary, Sayalkudi, Ramanathapuram District. Field examination revealed that the cow consumed sorghum which was sown 20 days before. Intravenous administration of Sodium thiosulfate @ $660 \mathrm{mg} / \mathrm{Kg}$ with one litre of normal saline and intravenous fluids resulted uneventful recovery of cow.

Keywords: Poisoning, immature sorghum, prussic acid, nondescript cow

\section{Introduction}

Cyanide poisoning or Prussic acid poisoning in livestock is one of the tantamount problem to dairy farmers. It is naturally present in young shoots of sorghum. It impairs the cellular respiration leading to a cascade of events culminating in cell death ${ }^{[1]}$.The incidence in ruminants are more common than monogastric animals ${ }^{[2]}$. Sorghum is one of the major cultivatable fodder in India mainly for livestock feeding. Rapid intake of sorghum equivalent to $4 \mathrm{mg} \mathrm{HCN} / \mathrm{Kg}$ is considered to be lethal [3]. Cyanide is very toxic to mammals and its effects may be noticed within 5-15 minutes after the consumption of cyanogenic plant. The brain and heart are the first to be affected by lack of oxygen and so the resulting clinical signs prior to death include excessive salivation, difficulty breathing, bright red mucous membranes, muscle tremors, convulsions, collapse and death from respiratory paralysis ${ }^{[4]}$. Cyanide occurs in the leaves of sorghum as cyanogenic glucoside dhurrin. During environmental stress and when leaf tissues are cracked large amount of dhurrin may be produced rapidly. It is observed that when $\mathrm{HCN}$ is readily absorbed into the blood stream of grazing ruminants, it causes death of animals. HCN production in forage is responsible for losses in livestock and hence, a great financial loss to poor rural livestock farmers of dry area. Variation of rainfall and temperature during crop growth period would affect HCN concentration. HCN accumulation will be on increase with the rise of temperature while reverse was true for seasonal precipitation. The present study describes the timely and prompt treatment given to save the life of animal as well as the farmer.

\section{Case History}

A farmer presented a history of a non descript, four years old cow suddenly fallen down while grazing and had severe tremors, to Veterinary Dispensary, Sayalkudi, Ramanathapuram District. We reached the incident place within few minutes. Physical examination revealed that the animal showed dyspnea, rapid and difficult breathing, dry muzzle, salivation, motionless eyes, congested mucous membranes, bloat, muscle tremors, convulsions and recumbency (Fig.1). Further interrogation with farmer revealed that the animal was allowed to graze in two to three weeks old grown fodder sorghum. It is confirmed that all the symptoms were mainly developed due to the consumption of sorghum fodder.

\section{Results and Discussions}

Based on history and clinical symptoms, the animal was treated for acute cyanide poisoning. Dark red colour blood was noticed while pricking for intravenous injection. The treatment was initiated with intravenous administration of sodium thiosulphate $(3 \%) @ 660 \mathrm{mg} / \mathrm{Kg}$ b.wt. diluted with $500 \mathrm{ml}$ of Normal saline. Followed by sodium nitrite $1 \%$ solution @ $22 \mathrm{mg} / \mathrm{Kg}$ b.wt mixed with $500 \mathrm{ml}$ of normal saline and administered intravenously. 
One litre of 5\% Dextrose and $500 \mathrm{ml}$ of Ringers lactate were administered intravenously. Injection Chlorpheniramine maleate $10 \mathrm{mg} / \mathrm{ml} @ 10 \mathrm{ml}$ and Dexamethasone Sodium 4 $\mathrm{mg} / \mathrm{ml} @ 10 \mathrm{ml}$ were given as intramuscularly. As the treatment progressed the symptoms gradually disappeared. In the verge of finishing the treatment the animal stood spontaneously showing uneventful recovery (Fig.2).

Sodium nitrite will convert haemoglobin to methaemoglobin, which react with cyanide to form cyanomethaemoglobin. A simultaneous injection of sodium thiosulphate provides sulphur to convert cyanomethaemoglobin to the non- toxic thiocyanate, which is excreted in urine ${ }^{[4]}$.

Ruminants are more susceptible than monogastric animals because ruminal microorganisms can rapidly break plant cells and release Cyanide ${ }^{[4]}$. In the ruminants, $\mathrm{pH}$ of the rumen is neither acidic nor alkaline, and it contains a large flora of micro-organisms and considerable quantities of enzymes. It acts as an excellent medium for the hydrolysis of the glycosides with the liberation of the toxic agent $\mathrm{HCN}$ that is then rapidly absorbed into the blood ${ }^{[3]}$.

Ramanathapuram is one of the draught prone district in Tamil Nadu which is more dry because of shortage of rainwater. The average annual rainfall ofthis district from South-West monsoon is $136.1 \mathrm{~mm}$ and North-East monsoon is $507.4 \mathrm{~mm}$ ${ }^{[5]}$. Draught condition is also one of the predisposing factor to increase the cyanide content in plants. Immature, wilted and draught affected plants are highly cyanogenic than the mature and normal plants ${ }^{(3)}$. Animals must not be allowed to graze in sorghum fields during drought periods when growth is severely reduced or the plant is wilted or twisted ${ }^{[6]}$.

\section{Acknowledgement}

The authors would like to thank The Regional Joint Director, Ramanathapuram and Tiruppur Districts for their guidance.

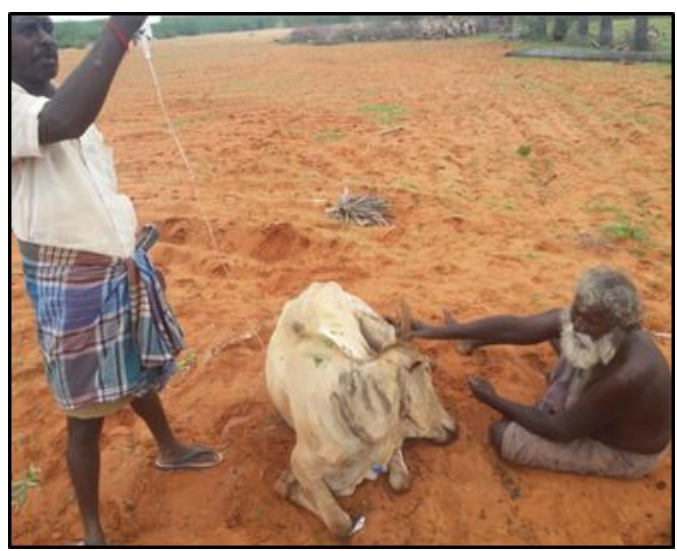

Fig 1: Animal In sternal recumbency therapy

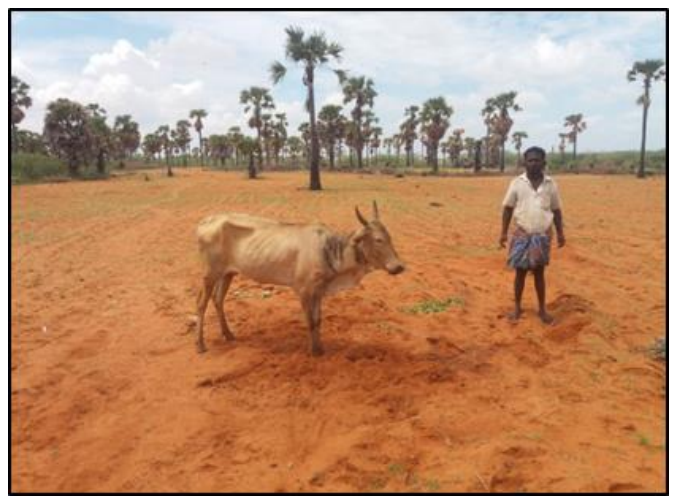

Fig 2: Fully recovered animal after under fluid Treatment

\section{References}

1. Bhattacharya R. Antidotes to cyanide poisoning: present status. Indian Journal of Pharmacology. 2000; 32:94-101.

2. Knight AP, Walter RG. A guide to plant poisoning of animals in North America. International Veterinary information service (www.ivis.org), Ithaca, New York, USA, 2002, 5.

3. Sinha RK, Kumari B, Kumar A, Kumar A, Azad CG. Sorghum poisoning in cattle and its therapeutic management. Journal of Agrisearch, 2019; 6(special issue): $108-109$.

4. Muwel N, Verma R, Nigwal D, Waskel L, Muwel M, Gurjar RS et al. Sorghum poisoning in buffaloes and its treatment. Journal of Pharmacognosy and Phytochemistry. 2018; 7(3):3737-3739

5. District survey report - Sand, Ramanathapuram District, Department of Geology and Mining, Government of Tamil Nadu, 2019, 16.

6. Yildiz K, Dokuzeylul B, Gonul R, Erman OR. Cyanide poisoning in cattle. Dairy and Vet Sci J. 2017; 1(4):jdvs.ms.id.555567. 